\title{
Nettfrekvente elektromagnetiske felt og helseeffekter
}

\author{
Karl Gerhard Blaasaas ${ }^{1}$ og Tore Tynes ${ }^{2}$ \\ 1) Forsvarets sanitet \\ 2) Statens strålevern \\ Korrespondanse: Karl Gerhard Blaasaas, Militærmedisinsk utdannings- og kompetansesenter, Bygning 0028A, 2058 Sessvollmoen \\ Telefon: 23097149 Telefax: 23097157 e-post: kblaasaas@mil.no
}

\begin{abstract}
SAMMENDRAG
I denne artikkelen oppsummeres epidemiologisk kunnskap om mulige helseeffekter etter eksponering for nettfrekvente $(50 / 60 \mathrm{~Hz})$ elektromagnetiske felt. Vi har basert oss på et flertall av vitenskapelige arbeider publisert i perioden 2001-2004 og konklusjoner i rapporter og oversiktsartikler fra perioden før 2001. Det er ikke funnet noen etiologisk sammenheng mellom elektromagnetiske felt og kronisk sykdom. Man vet heller ikke sikkert hvilke egenskaper ved de elektromagnetiske feltene som eventuelt kan fremskaffe sykdom. Eventuell latenstid fra eksponering til sykdomsutvikling er også ukjent. Eksponering over $0,4 \square \mathrm{T}$ fra kraftlinjer ser ut til å kunne gi en dobling i risikoen for barneleukemi, og basert på metaanalyser kan ikke resultatene avvises som tilfeldige funn. Holdepunktene for en slik sammenheng er likevel begrenset. Ved vokseneksponering har man i enkeltstudier observert risikoøkninger for brystkreft, leukemi, hjernesvulst og amyotrofisk lateralsklerose. Det er også gjort isolerte funn av abort blant kvinner eksponert under graviditeten. For alle disse endepunktene er funnene allikevel ikke tilstrekkelige til å trekke sikre konklusjoner om sammenheng med eksponering.
\end{abstract}

Blaasaaas KG, Tynes T. Power frequency electromagnetic fields and health effects. Nor J Epidemiol 2004; 14 (2): 177-186.

\section{ENGLISH SUMMARY}

This review is based on epidemiologic literature in the period 2001-2004 and conclusions in reports and review articles before 2001, regarding power frequency $(50 / 60 \mathrm{~Hz})$ electromagnetic fields and health outcomes. Twotimes increased risks for childhood leukaemia have been observed among children exposed to magnetic fields above $0.4 \mathrm{TT}$ from power lines, and based on meta-analyses these results can not be regarded as chance alone. The evidence for an association is however, still limited. Increased risks of breast cancer, leukaemia, brain tumor and amyotrophic lateral sclerosis have been observed in isolated studies. Increased risk of spontaneous abortion among women exposed during pregnancy has also been reported. None of the observations for any of these endpoints are, however, sufficient for any connection to electromagnetic field exposure.

\section{INTRODUKSJON}

Rundt alt elektrisk utstyr og alle strømførende ledninger finnes elektriske og magnetiske felt av varierende frekvens og styrke. Elektromagnetiske felt brukes som en kortform for elektriske og magnetiske felt og omfatter alle frekvenser fra statiske felt via nettfrekvente felt, radiobølger og synlig lys til radioaktiv stråling. For frekvenser i området for synlig lys og høyere sendes det ut energi fra kilden og man snakker om elektromagnetisk stråling. Ved lavere frekvenser skjer det i praksis ingen "utstråling" fra kilden og man snakker om elektromagnetiske felt. Egenskapene til feltet eller strålingen avhenger sterkt av frekvensen. Frekvenser over $1 \mathrm{THz}$, dvs. radioaktiv stråling og enkelte frekvenser av ultrafiolett stråling, har energi nok til å bryte kjemiske bindinger. Sterke felt med frekvens over omtrent $100 \mathrm{kHz}$, bl.a. radiobølger og mikrobølger, har energi nok til å gi oppvarming av kroppsvevet. Sterke felt under $1000 \mathrm{~Hz}$ kan indusere strømmer i kroppen og dermed påvirke nerver og muskler. Det er i dette området såkalte nettfrekvente felt finnes. I Norge og Europa brukes $50 \mathrm{~Hz}$ i strømnettet, mens frekvensen er $60 \mathrm{~Hz}$ i bl.a. USA og Japan. Felt som kan indusere strømmer i kroppen er imidlertid langt høyere enn de man kan oppleve i dagliglivet og det er bare i et fătall helt spesielle yrker som magnetpulvertesting, rydding av kraftlinjetraseer og arbeid under spenning man kan eksponeres så høyt.

Helt siden 1800-tallet har det vært diskutert hvorvidt elektromagnetiske felt, svakere enn de som gir akutte effekter, kan medføre helseeffekter. På den ene siden tilbys magnetfeltterapi som angivelig skal være helsebringende. På den annen side mener noen at magnetfelt nærmest per definisjon ikke kan påvirke levende vev. Mulige helseeffekter av lavfrekvente elektromagnetiske felt, særlig fra elektriske installasjoner og overføringsledninger, har vært sterkt mediefokusert, og mange er engstelige. Særlig har spørsmålet om kreft stått sentralt. I tillegg er Norge på verdenstoppen når det gjelder forbruk av elektrisk kraft.

En norsk ekspertgruppe avga i mai 2000 rapporten 
"Elektromagnetiske felt og helse. Vurdering av de siste fem års forskning 1995-2000" til Sosial- og helsedepartementet. Rapporten finnes på internett: http://www.odin.dep.no/hd/norsk/publ/rapporter/03005 1-220010/index-dok000-b-n-a.html (EMF2000). Rapporten omhandlet elektromagnetiske felt i frekvensområdet 10-60 Hz og konkluderte med at bortsett fra svake epidemiologiske holdepunkter for en sammenheng med leukemi hos barn var det ikke påvist skader og sykdommer som følge av svake elektromagnetiske felt.

I juni 2001 avsluttet International Agency for Research on Cancer (IARC) arbeidet med å klassifisere lavfrekvente magnetfelt med henblikk på kreft (IARC 2002). Nettfrekvente magnetfelt ble klassifisert som mulig kreftfremkallende for mennesker, basert på begrensede holdepunkter ("limited evidence") for en sammenheng mellom boligeksponering og barneleukemi.

Laboratoriestudier har ikke gitt entydige svar på om elektromagnetiske felt av den størrelsesorden man møter i dagliglivet kan påvirke biologiske effekter eller føre til kreft hos forsøksdyr (Ahlbom et al. 2001). Dyrestudier, verken in vitro eller in vivo støtter hypotesen om at lavfrekvente elektromagnetiske felt representerer skader på reproduksjonen (Brent 1999). Utfall som for tidlig fødsel, abort, nedsatt fertilitet og dødfødsel kan heller ikke undersøkes ved in vitroeksperimenter. De er også vanskelige å gjennomføre in vivo på ikke-primater.

I denne gjennomgangen vil vi hovedsakelig legge vekt på og oppsummere epidemiologisk kunnskapsstatus og eksponering for nettfrekvente elektromagnetiske felt. Vi har basert oss på et flertall av vitenskapelige arbeider funnet via Medline og publisert i perioden 2000-juni 2004 og konklusjoner i rapporter og oversiktsartikler til og med 2001. Vi legger primært vekt på sykdom som endepunkt og har gjort våre vurderinger med støtte i konklusjoner i rapporter og oversiktsartikler til og med 2001, med spesiell vekt på Ahlbom et al. (2001).

\section{EKSPONERINGSKARAKTERISERING}

Det er særlig tre problemstillinger som har vært diskutert $\mathrm{i}$ forbindelse med eksponering for elektromagnetiske felt; a) man vet ikke hvilken måleparameter og induksjonsperiode som er relevant, b) den retrospesifikke eksponeringsbedømmelsen og c) den ufullstendige karakteriseringen av eksponeringskilder uten mulighet for å kombinere eksponering fra ulike kilder inn i ett og samme mål.

a) Vi kjenner ikke den biologiske mekanismen for hvordan nettfrekvente elektromagnetiske felt av den størrelsesorden man utsettes for hjemme eller på jobb skal kunne gi helseskade. Derfor vet man ikke hvilke parametere det er aktuelt å måle eller hvilket tidsrom man trenger informasjon om for en gitt sykdom. De fleste epidemiologiske studier har studert magnetfelt- eksponering. Vegetasjon og bygninger skjermer ikke mot magnetfelt. Omgivelsene påvirker derimot det elektriske feltet og derfor er dette vanskeligere å måle. Det har også vært vanlig å bruke gjennomsnittsverdier som eksponeringsmål. Det har imidlertid vært argumentert med at siden feltene man utsettes for fra omgivelsene er så mye lavere enn det som må til for å indusere strømmer i kroppen, burde man isteden konsentrere seg om maksimumsverdier og raske forandringer av feltstørrelsen.

b) Alle epidemiologiske studer til nå baserer seg på retrospektiv eksponeringsbedømmelse, og siden utfallene av interesse er sjeldne er det lite trolig at prospektive studier vil bli gjennomført. Det diskuteres derfor om nøyaktige målinger av eksponeringssituasjonen $\mathrm{i}$ dag egner seg bedre eller dårligere enn mer usikre forsøk på å anslå feltverdiene historisk.

c) Eksponeringskarakteriseringen er aldri komplett. De fleste studier har basert seg på enten hjemme- eller yrkeseksponering. Man har ofte også fokusert på eksponering fra bestemte kilder som vannseng eller kraftlinjer hjemme og yrkeskoder eller ekspertvurdering av felteksponering i yrkessammenheng. I prinsippet kan man inkorporere alle eksponeringskilder ved å la deltagerne bære dosimeter, men også her vil man i praksis måtte ekstrapolere resultatene til tiden før en eventuell diagnose dersom studien skal kunne gjennomføres innenfor realistiske økonomiske eller tidsmessige rammer. Flytting og skifte av arbeidsoppgaver i tiden før en eventuell diagnose kompliserer også eksponeringsestimeringen. Forssén et al. (2002) undersøkte den relative betydningen av hjemme- og yrkes-/skoleeksponering blant personer bosatt i og rundt Stockholm. For personer som bodde nærmere enn 50 meter fra kraftlinjer bidro hjemmeeksponeringen med rundt $80 \%$ av totaleksponeringen. For voksne som bodde over 100 meter fra nærmeste kraftlinje bidro hjemmeeksponeringen med $38 \%$, mens tilsvarende tall for barn var $55 \%$.

Ahlbom et al. (2001) har oppsummert en rekke studier av eksponeringen i hjemmet. Flere studier har vist gode korrelasjoner mellom målinger tatt til forskjellige tider og annen eksponeringskarakterisering. O'Leary et al. (2003) sammenlignet kraftlinjekonfigurasjon, døgnmålinger av innendørs magnetfelt og andre karakteristika ved huset som kunne ha betydning for magnetfeltet i hus inkludert i en brystkreftstudie på Long Island. Korrelasjonen mellom ledningskonfigurasjon og målte verdier var god. Forssén et al. (2002) sammenlignet punktmålinger og beregninger av magnetfelt fra kraftlinjer med døgnmålinger i bolighus og rapporterte forholdsvis god sensitivitet og spesifisitet i begge tilfeller. Auvinen et al. (2000) sammenlignet ulike måleparametere fra barns soverom med risikoen for akutt lymfeoblastisk leukemi. Sentralmål og terskelverdier viste god korrelasjon med hverandre. Små risikoøkninger ble også assosiert med sentralmål. Risikoestimatene var noe høyere ved nattemålinger enn ved døgnmålinger. En studie som sammenlignet 
avstandsberegninger mellom hus og kraftlinjer målt på stedet med kartmålinger og beregninger via geografiske informasjonssystemer (GIS) fant klart bedre korrelasjon med kartmålinger enn GIS-beregninger (Blaasaas og Tynes 2002).

Lite er gjort angående pålitelighet og reproduserbarhet av yrkeseksponeringsvurderinger, dvs. om to uavhengige grupper ville komme frem til samme eksponeringsskjema for samme jobbtittel. For lite detaljerte jobbeksponeringsmatriser vil det trolig være godt samsvar, men langt lavere for mer detaljerte inndelinger (Ahlbom et al. 2001). Savitz et al. (2000) redefinerte en jobbeksponeringsmatrise brukt tidligere i en hjernekreft- og leukemistudie for et utvalg av materialet ved å dele jobbene inn i mer homogene grupper, men uten å gjøre ytterligere målinger. Den nye inndelingen hadde ikke innvirkning på resultatene fra de tidligere analysene. Magnetfelteksponeringer for et individ kan variere mye i løpet av en arbeidsdag, spesielt på en høyt eksponert arbeidsplass. Her kan eksponeringsmatrise basert på jobbtittel kunne gi like god karakterisering som personbåren dosimetri (Floderus 1996).

Generelt baserer amerikanske undersøkelser seg på uttrekk av kontroller fra telefonregistre. Dette kan føre til seleksjonsbias som følge av lav responsrate. Studiene vil også utelukke personer uten telefon. Blant disse er trolig personer fra lavere sosiale lag overrepresentert. I skandinaviske undersøkelser har man mulighet for å trekke populasjonsbaserte kontroller fra folkeregistre uten disse problemene. Både i studier av elektromagnetiske felt hjemme og på jobb kan resultatene være påvirket av at potensielle confoundere ikke har vært godt nok kartlagt. Studier der eksponeringen er basert på målte magnetfelt hos et lite utvalg personer $i$ et gitt yrke, vil ikke i tiltrekkelig grad gi informasjon om variasjonen i eksponering mellom individer $i$ samme yrke. Dette vil i de fleste tilfeller fore til at en eventuell effekt utvannes. Tre av de norske studiene (Kliukiene et al. 2004, Blaasaas et al. 2003, Blaasaas et al. 2002) har alle klassifisert yrkeseksponering basert på jobbtitler gitt hvert 10. år i folketellingene. Yrkeseksponeringsmatrisen var utarbeidet av et ekspertpanel. Dette gir rom for feilklassifisering. Flere av de svenske studiene (Feychting et al. 2000, Forssén et al. 2000, Håkansson et al. 2003b) har brukt Floderus et al.'s (1996) personbårne dosimetermålinger av menn i ulike yrker også i studier av kvinner. Svakheter i eksponeringsdataene vil kunne forplante seg i flere undersøkelser som omfatter ulike endepunkter.

\section{KREFT}

\section{Barnekreft}

Blant barn har det vært mest fokus på leukemi, men lymfom og hjernesvulst har også vært undersøkt, særlig i forhold til kraftledninger. Resultatene gir ikke overbevisende holdepunkt for at det er noen sammenheng mellom eksponering for elektromagnetiske felt fra kraftlinjer og hjernekreft eller lymfom (Ahlbom et al. 2001). Når det gjelder leukemi er det på grunnlag av en metaanalyse rapportert en dobling av relativ risiko blant barn bosatt $\mathrm{i}$ hus med eksponeringsnivå over 0,4 $\square \mathrm{T}$ (Ahlbom et al. 2000). Resultatet bygger imidlertid på små tall blant de høyt eksponerte, og betydningen av denne observasjonen er vanskelig å tolke uten en biologisk mekanisme eller eksperimentell støtte (Ahlbom et al. 2001).

Infante-Rivard og Deadman (2003) gjennomførte en casekontrollundersøkelse i Quebec hvor mødre ble intervjuet om yrkeshistorie under graviditeten, eksponering for elektromagnetiske felt ble estimert. Det ble observert en økt risiko for leukemi hos avkommet til de høyest eksponerte mødrene. En svensk kohortstudie observerte ingen sammenheng mellom mødrenes yrkeseksponering og kreft hos avkommet, men en økt risiko for leukemi ved eksponering av fedre over $0,3 \square \mathrm{T}$ (Feychting et al. 2000). En kanadisk/amerikansk undersøkelse av foreldereksponering og nevroblastomer hos avkommet observerte en svak ikke-signifikant økning etter eksponering av fedre utsatt for magnetfelt over $0,4 \square \mathrm{T}$. Det ble ikke rapportert økt risiko etter tilsvarende eksponering av mødre (De Roos et al. 2001).

To britiske studier fant ingen økt kreftrisiko hos barn verken i forhold til magnetfelt (UK Childhood Cancer Study Investigators 2000) eller elektriske felt (Skinner et al. 2002). Antallet høyt eksponerte barn var imidlertid lavt $\mathrm{i}$ førstnevnte studie. I et arbeid fra National Cancer Institute i USA ved Kleinerman et al. (2000) ble en oppfølgende analyse av tidligere publiserte casekontrolldata rapportert. For å nærmere undersøke spørsmålet om risiko for akutt lymfatisk leukemi blant barn som bor nær kraftledning, ble avstand til ulike ledninger og et eksponeringsmål basert på avstand og strømstyrke for boliger nærmere enn 40 meter etablert. Studien viste ingen sammenheng med leukemi. Schütz et al. (2001) fant ingen signifikant sammenheng for barneleukemi og eksponering for 24-timers målte magnetfelt. Magnetfelt målt om natten derimot, viste en signifikant assosiasjon. Når dataene ble slått sammen med data fra to tidligere tyske studier fra samme forskningsgruppe fant man en statistisk signifikant eksponeringsresponssammenheng for målte felt om natten. Dette var en forholdsvis stor studie, men antallet barn eksponert for magnetfelt over $0,2 \mu \mathrm{T}$ var imidlertid lavt, noe som gav upresise risikoestimater. Bianchi et al. (2000) rapporterte økt leukemirisiko og et eksponeringsresponsforhold i en mindre studie blant barn bosatt langs kraftlinjer i Italia. To metaanalyser av barneleukemi rapporterte en økt leukemirisiko ved magnetfelteksponering høyere enn $0,3 \square \mathrm{T}$ (Greenland et al. 2000) eller 0,4 $\square$ T (Ahlbom et al. 2000). Sistnevnte antyder imidlertid at seleksjonsbias kan forklare noe av den økte risikoen. Tilsvarende resultater ble ikke funnet i forhold til ledningskonfigurasjon.

En studie ved Söderberg et al. (2002) fant liten støtte til at eksponering for magnetfelt i kuvøser på en nyfødtavdeling kan være assosiert med leukemi hos 
barn, selv om det ble rapportert en ikke-signifikant økt risiko uten eksponerings-responsforhold for akutt myelogen leukemi.

\section{Kreft hos voksne}

Mesteparten av litteraturen dreier seg om yrkeseksponering, særlig har brystkreft, leukemi og hjernekreft vært studert.

\section{Brystkreft}

Siden det finnes få kvinner i "elektriske" yrker, dreier de fleste studier av brystkreft hos kvinner seg om hjemmeeksponering. For mannlig brystkreft dominerer yrkeseksponeringsstudier. Holdepunktene for en sammenheng mellom elektromagnetiske felt og brystkreft er imidlertid svake (Ahlbom et al. 2001).

En casekontrollstudie av kvinnelig brystkreft og hjemmeeksponering fra Long Island som inkluderte punktmålinger, 24-timersmålinger i flere rom, ledningsoppheng, og måling av jordstrøm observerte ingen sammenheng med brystkreft (Schoenfeld et al. 2003). Det gjorde heller ikke London et al. (2003) og Davis et al. (2002) i sine studer fra henholdsvis Los Angeles og Seattle. Fire studier av brystkreft blant brukere av elektriske varmetepper rapporterte ingen sammenheng med slik bruk (Laden et al. 2000, Zheng et al. 2000, McElroy et al. 2001, Kabat et al. 2003). Zhu et al. (2003) på den annen side observerte en assosiasjon med bruk av elektrisk sengevarme blant afroamerikanske kvinner basert på telefonintervjuer.

Labreche et al. (2003) studerte yrkeseksponering blant kvinner og fant indikasjoner på en svak risikoøkning for brystkreft blant postmenopausale kvinner, men bare statistisk signifikant $i$ et underutvalg av kvinner eksponert for fylte 35 år og med progesteronpositive tumorer. Tallene var basert på yrkeshistorie og ekspertvurderinger av magnetfelteksponering i ulike yrker. Van Wijngaarden et al. (2001) fant lite støtte til hypotesen om at magnetfelteksponering i yrket gir brystkreft, selv om enkelte risikoestimater for eksponerte premenopausale kvinner og kvinner med østrogenreseptorpositive svulster var forhøyet.

Forssén et al. (2000) rapporterte en casekontrollstudie blant kvinner bosatt nærmere enn 300 meter fra kraftlinjer i Sverige. Magnetfeltet fra kraftlinjene ble beregnet. Det ble også innhentet yrkesopplysninger fra folketellinger og yrkene ble koblet til en jobbeksponeringsmatrise basert på magnetfeltdosimetri blant menn $\mathrm{i}$ en annen studie. Det ble funnet økt risiko for kvinner under 50 år på diagnosetidspunktet, særlig for kombinert eksponering og østrogenreseptorpositiv kreft, men ikke statistisk signifikant (kun fire eksponerte cases). Forfatterne konkluderte med at de ikke fant støtte til en økning av brystkreft totalt og at observasjonene i de lavere aldersgruppene bare kan betraktes som svake indikasjoner på en sammenheng mellom magnetfelt og brystkreft. Kliukiene et al. (2004) studerte brystkreft blant kvinner som bodde i en korridor langs høyspentledninger i Norge. Yrkesopplysninger fra folketellin- ger ble også koblet til en yrkeseksponeringsmatrise basert på ekspertvurderinger av magnetfelt. Blant kvinner med hjemmeeksponering for magnetfelt over $0,05 \mu \mathrm{T}$ ble det rapportert $60 \%$ økning i risikoen for brystkreft. Forfatterne konkluderte med at resultatene viste en assosiasjon mellom magnetfelteksponering og brystkreft, mer uttalt for hjemmeeksponering enn for yrkeseksponering.

En undersøkelse av mannlig brystkreft og yrkeseksponering i Sverige (Pollan et al. 2001) brukte samme jobbeksponeringsmatrise som Forssén et al. (2001). Det ble observert økt risiko i flere yrkesgrupper, men konsistent bare for maskinreparatører. Det ble også observert et eksponeringsresponsforhold blant ansatte $\mathrm{i}$ yrker med intermitterende eksponering, og forfatterne konkluderer med at variasjoner i eksponering over en arbeidsdag kan være assosiert med en økt risiko for brystkreft.

En metaanalyse av epidemiologiske studier av elektromagnetiske felt og brystkreft hos både menn og kvinner gjennomgår 43 publikasjoner (Erren 2001). 24 av studiene gir estimater for relativ risiko for kvinner med et gjennomsnitt på 1,12 (1,09-1,15). Tilsvarende for menn basert på 15 studier gir 1,37 (1,11-1,71). Selv om resultatene til sammen kan tyde på en liten risikoøkning, er det liten konsistens mellom de enkelte studiene og forfatteren mener det er for tidlig å konkludere med at observasjonene reflekterer en virkelig sammenheng.

\section{Leukemi}

De aller fleste studier vedrørende leukemi dreier seg om yrkeseksponering. Resultatene varierer fra ingen til sterk assosiasjon, men det er ikke noe mønster som at gode studier oftere gir positive assosiasjoner (Ahlbom et al. 2001).

Villeneuve et al. (2000a) rapporterte leukemi blant ansatte i elektrisitetsforsyning i Canada. Dataene tydet på at tid i elektriske felt over 20 og $39 \mathrm{~V} / \mathrm{m}$ kunne prediktere leukemirisikoen. Det ble også observert en sammenheng med eksponering for elektriske felt blant de som hadde arbeidet i mer enn 20 år i høyeste tertil for prosentandel av tid i felt over 10 og $20 \mathrm{~V} / \mathrm{m}$. Det ble ikke funnet noen assosiasjon med magnetfelt. En britisk studie av leukemidødelighet blant ansatte i det tidligere Central Electricity Generating Board of England and Wales, viste ingen økt risiko som følge av eksponering for magnetfelt (Harrington et al. 2001). Minder og Pflüger (2001) rapporterte en eksponeringsresponssammenheng mellom dødelighet av leukemi og eksponering for lavfrekvente magnetfelt blant ansatte på den sveitsiske jernbanen. Studien var basert på målinger og historisk rekonstruksjon av eksponering. Studien baserer seg på små tall i de ulike eksponeringskategoriene, og man kan derfor ikke utelukke at andre eksponeringsforhold kan ha bidratt til den økte leukemidødeligheten. Bethwaite et al. (2001) rapporterte en populasjonsbasert casekontrollstudie av akutt leukemi og ansettelse i elektriske yrker fra New Zealand. Stu- 
dien viste en signifikant økt risiko totalt, og i et mindre utvalg for sveisere/skjærebrennere og telefonlinjearbeidere. Det ble også vist en eksponeringsresponssammenheng. Willett et al. (2003) observerte en økt risiko for lymfoblastisk leukemi blant kvinner vurdert som sannsynlig yrkeseksponert for elektromagnetiske felt $\mathrm{i}$ forhold til kvinner vurdert som ueksponert. Det ble ikke observert økt risiko blant menn eller for andre undergrupper av leukemi verken for menn eller kvinner. Forfatterne vurderer det også som usannsynlig at magnetfelteksponeringen var ansvarlig for overrisikoen for lymfoblastisk leukemi. Tynes og Haldorsen (2003) fant ingen sammenheng mellom eksponering for magnetfelt $\mathrm{i}$ bolig eller på jobb og leukemi eller annen hematologisk kreft hos voksne.

\section{Hjernesvulst}

Resultatene fra tidligere studier av kreft i sentralnervesystemet og eksponering for elektromagnetiske felt stammer primært fra yrkeseksponeringsstudier og varierer fra ingen til sterk positiv sammenheng og gjør at man ikke kan trekke noen konklusjoner om en eventuell sammenheng (Ahlbom et al. 2001).

Sorahan et al. (2001) fant ingen økt risiko for hjernekreft blant ansatte i det tidligere Central Electricity Generating Board of England and Wales i forhold til magnetfelt. Harrington et al. (2001) rapporterte dødelighet av hjernesvulst blant ansatte $\mathrm{i}$ det tidligere Central Electricity Generating Board of England and Wales. Ingen sammenheng med eksponering for magnetfelt ble funnet. Villeneuve et al. (2002) rapporterte hjernesvulst $i$ en populasjonsbasert casekontrollstudie der yrker ble klassifisert med hensyn på magnetfelteksponering. Blant menn diagnostisert med glioblastoma multiforme ble det vist en signifikant økning i risiko (odds ratio: 5,36). Zheng et al. (2001) rapporterte en populasjonsbasert casekontrollstudie av hjernesvulst og yrke. Analysen viste en økt risiko blant menn ansatt i "elektriske serviceyrker" (electrical services). Det samme ble vist for kvinner i produksjon av elektrisk og elektronisk utstyr. Minder og Pflüger (2001) fant ingen økt dødelighet av hjernekreft blant sveitsiske jernbaneansatte. Navas-Acien et al. (2002) undersøkte interaksjonen mellom magnetfelt og ni kjemikalier mistenkt for å være kreftfremkallende i forhold til gliomer og meningiomer $i$ en kohort av mannlige svenske arbeidstagere. Det ble observert en økning av gliomer ved samtidig eksponering for elektromagnetiske felt og henholdsvis løsemidler, bly og pesticider. Forfatterne konkluderer imidlertid med at det er nødvendig å bekrefte funnene i nye undersøkelser før man kan konkludere med at der er en reell interaksjonseffekt.

\section{Annen kreft}

To andre krefttyper er referert hos Ahlbom et al. (2001). En kanadisk-fransk studie fant en assosiasjon mellom pulsete elektromagnetiske felt og lungekreft. Tilsvarende assosiasjon ble ikke reprodusert $i$ en senere amerikansk studie. Det er også funnet noe støtte for en assosiasjon med non-Hodgkins lymfom. I tillegg er risikoøkninger for andre krefttyper sporadisk funnet i studier hvor designet tillot at man undersøkte alle typer kreft.

I en casekontrollstudie av non-Hodgkins lymfom og $60 \mathrm{~Hz}$ elektromagnetiske felt blant mannlige kraftforsyningsansatte i Ontario fant Villeneuve et al. (2000b) en økning i kreftforekomsten blant personell eksponert for elektriske felt over $10 \mathrm{og} 40 \mathrm{~V} / \mathrm{m}$ i den øve tidstertilen relativt til den laveste. Forfatterne konkluderer imidlertid med at det trengs flere studier for å bekrefte funnene. Baumgardt-Elms et al. (2002) fant ingen økning av testikkelkreft $\mathrm{i}$ en tysk casekontrollundersøkelse hvor 269 case og 797 kontroller ble intervjuet om de hadde arbeidet i nærheten av bl.a. elektriske maskiner, kraftledninger, overføringsinstallasjoner eller dataskjermer. En liten amerikansk studie undersøkte livmorkreft og bruk av elektrisk varmeteppe, men fant ingen forskjell i krefthyppighet blant brukere og ikke-brukere (McElroy et al. 2002). Håkansson et al. (2002) undersøkte kreftforekomst i bransjer som drev med motstandssveising i Sverige. De ansatte ble delt i fire eksponeringskategorier basert på jobbtitler etter kobling til en jobbeksponeringsmatrise basert på dosimetrimålinger. Det ble funnet indikasjoner på et eksponerings-responsforhold for kreft i nyre, hypofyse, galleveier og lever for menn og astrocystom for kvinner. For kvinner fant man også indikasjoner på en økt risiko for myelomatose og livmorkreft i den høyeste eksponeringskategorien.

Fra en norsk studie (Tynes et al. 2003) av malignt melanom blant voksne bosatt nær høyspentledning ble det rapportert en sammenheng med eksponering for magnetfelt fra ledningene, spesielt for kvinner, men tilsvarende resultater er ikke observert $i$ andre studer.

\section{NEVRODEGENERATIVE LIDELSER}

Det overveldende flertallet av studier har vært lagt på amyotrofisk lateralsklerose og Alzheimers sykdom. Studiene av amyotrofisk lateralsklerose har undersøkt yrkeseksponerte og peker i retning av en mulig økt risiko ved eksponering for elektromagnetiske felt. Flere studier der man kan se på andre eksponeringsforhold av betydning, særlig eksponering for elektrisk støt, er likevel nødvendige (Ahlbom et al. 2001). Likelydende konklusjon har Li og Sung (2003) i sin litteraturgjennomgang av amyotrofisk lateralsklerose og yrkeseksponering for nettfrekvente elektromagnetiske felt. Positive funn for Alzheimers sykdom har vært begrenset til studier med svakt design, slik at støtten for en slik sammenheng med elektromagnetiske felt er liten (Ahlbom et al. 2001). For andre sykdommer som Parkinsons sykdom og multippel sklerose er resultatene for mangelfulle til å trekke noen konklusjoner (Ahlbom 2001).

Johansen (2000) undersøkte forekomst av kroniske nevrologiske lidelser blant ansatte i dansk kraftforsyning. Studien viste en økt risiko for senil demens og multippel sklerose for de som var klassifisert som mu- 
lig eksponert for elektromagnetisk felt. Forekomsten av Parkinsons sykdom, Alzheimers sykdom og andre sykdommer i sentralnervesystemet viste ingen assosiasjon med eksponering for elektromagnetiske felt. Håkansson et al. (2003a) undersøkte dødelighet av nevrodegenerative sykdommer i en kohort av 537692 svenske menn og 180529 kvinner ved å koble yrkesopplysningene $\mathrm{i}$ tre folketellinger mot en eksponeringsdatabase basert på magnetfeltmålinger. Det ble observert en eksponeringsresponssammenheng for både amyotrofisk lateralsklerose og Alzheimers sykdom, men ingen sammenheng for multippel sklerose og Parkinsons sykdom.

\section{DEPRESJONER OG SELVMORD}

Det er gjort flere studier angående selvmord og elektromagnetiske felt, men resultatene er inkonsistente. Flere innfallsvinkler har vært brukt og eksponeringskarakteriseringen har variert fra yrkestittel og avstand til kraftlinje til detaljerte kohorter av kraftforsyningsansatte. Ahlbom et al. (2001) oppsummerer med at de tidligste studiene av selvmord hadde metodiske svakheter og at funnene derfra ikke kan tillegges stor vekt, men at det senere er gjort studier som antyder at en sammenheng kan eksistere. Holdepunktene for en sammenheng er imidlertid svake (Ahlbom 2001). Når det gjelder depresjoner er resultatene også her inkonsistente og mange av studiene har metodologiske svakheter slik at resultatene er vanskelige å tolke (Ahlbom et al. 2001).

En amerikansk casekontrollundersøkelse (van Wijngaarden et al. 2000) blant kraftforsyningsansatte klassifiserte eksponeringen på bakgrunn av jobbtype og magnetfeltmålinger. Forekomsten av selvmord var forhøyet blant elektrikere (odds ratio: 2,18; 95\% konfidensintervall: 1,25-3,80) og linjemenn (odds ratio: 1,59; 95\% konfidensintervall: 1,18-2,14) og man fant en eksponerings-responssammenheng $\mathrm{i}$ forhold til eksponering foregående år, størst hos menn under 50 år.

\section{REPRODUKSJON}

En rekke studier av reproduksjonsutfall blant foreldre potensielt eksponert for 50/60 Hz elektromagnetiske felt er gjennomført. De fleste studiene dreier seg om enten hjemme- eller yrkeseksponering. I hjemmeeksponeringsstudiene har bruk av elektriske varmetepper, vannsenger eller bolig nær kraftledninger vært brukt som eksponeringsmål. Yrkeseksponeringsstudiene kan deles $\mathrm{i}$ arbeid med dataterminaler og annen yrkeseksponering. En rekke endepunkter som fødselsvekt, for tidlig fødsel, kjønnsratio, fødsel, spontanabort, dødfødsel, sædkvalitet og misdannelser har vært undersøkt. Få studier har vært store nok til å kunne gå inn på de enkelte misdannelser og dermed bare behandlet misdannelser som en felles kategori. Resultatene har vært inkonsistente og flere oppsummeringsartikler har konkludert med at man ikke har overbevisende holdepunk- ter for at elektromagnetiske felt av den størrelsesorden gravide kvinner og potensielle fedre utsettes for på jobb eller i dagliglivet kan skade reproduksjonsprosessen (Ahlbom et al. 2001, Robert 1999). På den annen side er det gjort for få studier som involverer direkte målinger og multiple eksponeringskilder til at man kan trekke bastante konklusjoner (Shaw 2001).

Blaasaas et al. (2002) studerte misdannelser blant barn født av foreldre med mulig eksponering for magnetfelt i yrket. Undersøkelsen omfattet alle fødsler i Norge i perioden 1967-1995 og viste en assosiasjon med utvalgte misdannelser i sentralnervesystemet. Resultatene må imidlertid tolkes med forsiktighet siden eksponeringskarakteriseringen bare var basert på yrkeskoder fra tre folketellinger og mange sammenligninger som ble gjort.

I en studie av medfødte misdannelser (Blaasaas et al. 2003) som omfattet alle norske fødsler i perioden 1980-august 1997 ble avstand mellom mødrenes bolig under graviditeten og nærmeste kraftlinje beregnet, linjens strømbelastning innhentet og magnetfeltet $\mathrm{i}$ boligen beregnet. Det ble observert en halvert risiko for hjerte- og respirasjonssystemdefekter blant barn av mødre bosatt $i$ boliger med magnetfeltverdier over 0,1 $\square$ T. En senere casekontrollstudie (Blaasaas et al. 2004) med forbedret eksponeringskarakterisering i et utvalg av materialet fant imidlertid ingen effekt av magnetfelteksponering. Blaasaas et al. (2003) undersøkte også kombinert yrkes- og hjemmeeksponering uten å finne $ø \mathrm{kt}$ risiko for misdannelser.

Lee et al. (2000) undersøkte klinisk verifisert spontanabort blant brukere av elektriske varmetepper. Det ble ikke funnet noen negativ effekt ved bruk av varmeteppe. Lee et al. (2002) gjennomførte en annen studie der klinisk verifisert abort og eksponering for magnetfelt ble analysert. Kraftlinjekonfigurasjon, punktmålinger, døgngjennomsnitt, gjennomsnittlig differanse mellom påfølgende nivåer ("rate-of-change metric") og maksimumsnivå ble vurdert. For kraftlinjekonfigurasjon og områdemålinger fant man ingenting, for "rateof-change metric" vurdert ved kvartiler fant man en økende risiko ved økende kvartil relativt til laveste kvartil. Det samme gjaldt maksimumsnivå. Døgngjennomsnitt ga en ikke-signifikant odds ratio på 1,7 for alle de øvre kvartiler. Lav responsrate fra mulige tilfeller og kontroller kan ha ført til seleksjonsbias. Deltagende case kom oftere fra hus i nærheten av høykonfigurerte kraftlinjer enn ikke-deltagende case. Dette var ikke tilfelle for kontroller og man fant ingen sammenheng mellom kraftlinjekonfigurasjon og spontanabort. Persondosimetriens validitet ble evaluert ved å sammenligne målinger tatt 30 . uke etter siste menstruasjon med målinger gjort $\mathrm{i}$ et underutvalg 12 uker etter siste menstruasjon. De to settene var dårlig korrelert, noe som svekker tilliten til resultatene. Li et al. (2002) publiserte en kohortstudie av abort blant kvinner med positiv graviditetstest før 10. uke. Kvinner inkludert i studien bar dosimeter for måling av magnetfelt i 24 timer. Det ble ikke vist assosiasjon mellom 
abort og gjennomsnittlig magnetfeltnivå, men abortrisikoen var høyere ved maksimalverdi over en terskel på 1,6 $\square \mathrm{T}$. Assosiasjonen var sterkere for de med tidlige aborter $(<10$. uke) og blant de mer utsatte (tidligere abort eller subfertilitet). Også her foreligger mulighet for seleksjonsbias. Mer enn halvparten av abortene skjedde før måling av magnetfelt ble foretatt. I en lederartikkel (Savitz 2002) som diskuterte de to overnevnte arbeidene ble oppmerksomheten henledet mot at assosiasjonen med maksimalt felt kunne være falsk. Dette fordi kvalme er assosiert med redusert risiko for abort og kvalme kan gi redusert mobilitet (lengre opphold på samme sted) og dermed mindre mulighet for å være eksponert for høye magnetfeltnivåer. Dermed vil vellykkede svangerskap ha lavere maksimumsverdi. Li og Neutra (2002) har imidlertid avvist denne muligheten.

\section{HJERTEKARSYKDOM}

Ahlbom et al. (2001) oppsummerer studier vedrørende mulige kardiovaskulære virkninger av elektromagnetiske felt. Det har vært foreslått at eventuelle effekter er relatert direkte til hjertefrekvensen. Man kjenner ikke til forandringer $\mathrm{i}$ andre parametere som elektrokardiogram eller blodtrykk. Ahlbom et al. konkluderer imidlertid med at indikasjoner på kardiovaskulære effekter etter magnetfelteksponering er svake, og om det finnes sammenhenger med elektromagnetiske felt forblir spekulasjoner inntil resultater fra større epidemiologiske studier foreligger.

Johansen et al. (2002) koblet en kohort på 24056 menn ansatt i kraftselskaper mellom 1982 og 2000 med det danske pacemakerregisteret. Det ble ikke funnet noen $ø \mathrm{kt}$ risiko for alvorlig hjerterytmeforstyrrelse blant de ansatte og heller ikke noe eksponeringsresponsforhold med felteksponering eller ansettelsestid. Sorahan og Nichols (2004) fant ingen økt risiko for å dø av hjerterytmeforstyrrelser, hjerteinfarkt, aterosklerose eller kroniske og subbakutte hjertesykdommer blant 83997 ansatte i daværende Central Electricity Generating Board of England and Wales. Sahl et al. (2002) fant heller ikke økt dødelighet av verken hjerteinfarkt eller kronisk kransarteriesykdom blant 35391 ansatte i Southern California Edison Company. Håkansson et al. (2003b) koblet yrkesopplysninger i 1967 og 1973 til 27790 personer i det svenske tvillingregisteret til en jobbeksponeringsmatrise basert på målte magnetfeltverdier i ulike yrkesgrupper. For hjerteinfarkt fant man en liten økning i dødsrisiko for høyt eksponerte. For død som følge av hjerterytmeforstyrrelser, aterosklerose eller andre ischemiske hjertesykdommer fant man ingen sammenheng.

\section{OPPSUMMERING OG KONKLUSJONER}

\section{Kreft}

Store og godt gjennomførte studier har gitt bedre data enn det som har vært tilgjengelig tidligere når det gjelder eventuell sammenheng mellom lavfrekvente magnetfelt og kreftrisiko. For barn under 15 år ser eksponering over $0,4 \square \mathrm{T}$ ut til å kunne gi en dobling $\mathrm{i}$ risikoen for leukemi, og metaanalyser konkluderer med at resultatene ikke kan avvises som tilfeldige funn. Dersom en sammenheng eksisterer må vi anta at mangelfull eksponeringsklassifisering kan gi for lave risikoestimater ved eksponering lavere enn 0,4 $\square \mathrm{T}$. Holdepunktene for en slik sammenheng er likevel begrenset. En samlet vurdering av studier som har sett på hjernesvulst og andre kreftformer blant barn og magnetfelteksponering gir ikke holdepunkt for en sammenheng.

Vi har i dag ikke grunn til å anta at eksponering i hjemmemiljøet skal kunne gi kreft hos voksne. Selv om resultatene er motstridende, har enkelte studier funnet en økning av brystkreft både etter yrkes- og hjemmeeksponering. Gitt den høye forekomsten av brystkreft blant kvinner bør disse spørsmålene undersøkes videre i nye og godt gjennomførte yrkes- og boligstudier med god eksponeringsklassifisering. Når det gjelder yrkeseksponering og annen kreft, representerer den senere tids undersøkelser forbedringer både med hensyn til design, eksponeringsutvurdering og statistisk styrke. Enkelte studier har imidlertid observert risikoøkninger. Dette gjelder i hovedsak leukemi og svulster i hjernen. Resultatene for undertyper av leukemi er vanskelige å vurdere, men flere ekspertutvalg har pekt på kronisk lymfatisk leukemi som en type svulster som i flere studier har vist en økt risiko. Det er i dag likevel ikke mulig å gjøre en sikker risikovurdering i forhold til yrkeseksponering og leukemi og hjernesvulst.

\section{Andre endepunkter}

Det finnes ikke holdepunkter for en sammenheng mellom kvinners bruk av datamaskin og abort eller andre reproduksjonsskader. Det finnes imidlertid isolerte funn av abort etter magnetfelteksponering, men mangelen på data når det gjelder foreldereksponering for elektromagnetiske felt og negative svangerskapsutfall gir foreløpig ikke anledning til å trekke valide vitenskapelige konklusjoner.

Indikasjonene for økt risiko for amyotrofisk lateralsklerose er bekreftet $i$ enda en studie, men svakhetene $i$ eksponeringskarakteriseringen gjør at man allikevel ikke kan konkludere med økt risiko. Selv om det finnes enkelte svake holdepunkter for økt selvmordsfrekvens kan man ikke her trekke noen konklusjoner enda. Man har i dag ikke holdepunkter for økt risiko for hjerte- eller sirkulasjonsskader. Resultater vedrørende depresjoner er også for inkonsistente til å påvise en sammenheng. Andre endepunkter har enten vært for lite undersøkt eller ikke vist positive assosiasjoner.

På bakgrunn av manglende bevis fra dyre- og cellestudier og usikkerheten og inkonsistensen i epidemiologiske studier, er det ikke etablert noen etiologisk sammenheng mellom elektromagnetiske felt og noen kroniske sykdommer. Man vet heller ikke sikkert hvil- 
ke egenskaper ved de elektromagnetiske feltene som eventuelt kan fremskaffe sykdom, selv om man har observert en økning av barneleukemi ved magnetfelteksponering over 0,4 $\square \mathrm{T}$. Eventuell latenstid fra eksponering til eventuell sykdomsutvikling er også ukjent. Alle disse forhold gjør at man må være forsiktig med å trekke konklusjoner om mulige skadelige effekter av elektromagnetiske felt.

\section{REFERANSER}

Ahlbom A. Neurodegenerative diseases, suicide and depressive symptoms in relation to EMF. Bioelectromagnetics 2001; Suppl 5: S132-S143.

Ahlbom A, Cardis E, Green A, Linet M, Savitz D, Swerdlow A. Review of the epidemiologic literature in EMF and health. Environ Health Persp 2001; 109 (suppl 6): 911-933.

Ahlbom A, Day N, Feychting M, et al. A pooled analysis of magnetic fields and childhood leukaemia. $\mathrm{Br} J$ Cancer 2000; 83 (5): 692-698.

Auvinen A, Linet MS, Hatch EE, et al. Extremely low-frequency magnetic fields and childhood acute lymphoblastic leukemia: an exploratory analysis of alternative exposure metrics. Am J Epidemiol 2000; 152 (1): 20 31.

Baumgardt-Elms C, Ahrens W, Bromen K, et al. Testicular cancer and electromagnetic fields (EMF) in the workplace: results of a population-based case-control study in Germany. Cancer Causes Control 2002; 13 (10): 895-902.

Bethwaite P, Cook A, Kennedy J, Pearce N. Acute leukemia in electrical workers: a New Zealand case-control study. Cancer Causes Control 2001; 12 (8): 683-689.

Bianchi N, Crosignani P, Rovelli A, et al. Overhead electricity power lines and childhood leukemia: a registrybased, case-control study. Tumori 2000; 86 (3): 195-198.

Blaasaas KG, Tynes T. Comparison of three different ways of measuring distances between residences and high voltage power lines. Bioelectromagnetics 2002; 23 (4): 288-291.

Blaasaas KG, Tynes T, Irgens A, Lie RT. Risk of birth defects by parental occupational exposure to $50 \mathrm{~Hz}$ electromagnetic fields: a population based study. Occup Environ Med 2002; 59 (2): 92-97.

Blaasaas KG, Tynes T, Lie RT. Residence near power lines and the risk of birth defects. Epidemiology $2003 ; 14$ (1): 95-98.

Blaasaas KG, Tynes T, Lie RT. Risk of selected birth defects by maternal residence close to power lines during pregnancy. Occup Environ Med 2004; 61 (6): 174-176.

Brent RL. Reproductive and teratologic effects of low-frequency electromagnetic fields: A review of in vivo and in vitro studies using animal models. Teratology 1999; 59 (4): 261-286.

Davis S, Mirick DK, Stevens RG. Residential magnetic fields and the risk of breast cancer. Am J Epidemiol 2002; 155 (5): 446-454.

De Roos AJ, Teschke K, Savitz DA, Poole C, Grufferman S, Pollock BH, Olshan AF. Parental occupational exposures to electromagnetic fields and radiation and the incidence of neuroblastoma in offspring. Epidemiology 2001; 12 (5): 508-517.

EMF2000. Elektromagnetiske felt og helse. Vurdering av siste fem års forskning 1995-2000. Rapport. Sosial- og helsedepartementet. Juni 2000.

Erren TC. A meta-analysis of epidemiologic studies of electric and magnetic fields and breast cancer in women and men. Bioelectromagnetics 2001; Suppl 5: S105-S119.

Feychting M, Floderus B, Ahlbom A. Parental occupational exposure to magnetic fields and childhood cancer (Sweden). Cancer Causes Control 2000; 11 (2): 151-156.

Floderus B. Is job title an adequate surrogate to measure magnetic field exposure? Epidemiology $1996 ; 7$ (2): 115 116.

Floderus B, Persson T, Stenlund C. Magnetic-field exposures in the workplace: Reference distribution and exposures in occupational groups. Int J Occup Environ Health 1996; 2 (3): 226-238.

Forssén UM, Ahlbom A, Feychting M. Relative contribution of residential and occupational magnetic field exposure over twenty-four hours among people living close to and far from a power line. Bioelectromagnetics 2002; 23 (3): 239-244.

Forssén UM, Feychting M, Rutqvist LE, Floderus B, Ahlbom A. Occupational and residential magnetic field exposure and breast cancer in females. Epidemiology 2000; 11 (1): 24-29.

Greenland S, Sheppard AR, Kaune WT, Poole C, Kelsh MA. A pooled analysis of magnetic fields, wire codes, and childhood leukemia. Epidemiology 2000; 11 (6): 624-634. 
Harrington JM, Nichols L, Sorahan T, van Tongeren M. Leukaemia mortality in relation to magnetic field exposure: findings from a study of United Kingdom electricity generation and transmission workers, 1973-97. Occup Environ Med 2001; 58 (5): 307-314.

Håkansson N, Floderus B, Gustavsson P, Johansen C, Olsen JH. Cancer incidence and magnetic field exposure in industries using resistance welding in Sweden. Occup Environ Med 2002; 59 (7): 481-486.

Håkansson N, Gustavsson P, Johansen C, Floderus B. Neurodegenerative diseases in welders and other workers exposed to high levels of magnetic fields. Epidemiology 2003a; 14 (4): 420-426.

Håkansson N, Gustavsson P, Sastre A, Floderus B. Occupational exposure to extremely low frequency magnetic fields and mortality from cardiovascular disease. Am J Epidemiol 2003b; 158 (6): 534-542.

IARC Working Group on the Evaluation of Carcinogenic Risks to Humans. Non-ionizing radiation. Part 1: static and extremely low-frequency (ELF) electric and magnetic fields. IARC Monogr Eval Carcinog Risks Hum 2002; 80: 1-395.

Infante-Rivard C, Deadman JE. Maternal occupational exposure to extremely low frequency magnetic fields during pregnancy and childhood leukemia. Epidemiology 2003; 14 (4): 437-441.

Johansen C. Exposure to electromagnetic fields and risk of central nervous system disease in utility workers. Epidemiology 2000; 11 (5): 539-543.

Johansen C, Feychting M, Moller M, Arnsbo P, Ahlbom A, Olsen JH. Risk of severe cardiac arrhythmia in male utility workers: a nationwide danish cohort study. Am J Epidemiol 2002; 156 (9): 857-861.

Kabat GC, O'Leary ES, Schoenfeld ER, et al; EBCLIS Group. Electric blanket use and breast cancer on Long Island. Epidemiology 2003; 14 (5): 514-520.

Kleinerman RA, Kaune WT, Hatch EE, et al. Are children living near high-voltage power lines at increased risk of acute lymphoblastic leukemia? Am J Epidemiol 2000; 151 (5): 512-515.

Kliukiene J, Tynes T, Andersen A. Residential and occupational exposures to 50-Hz magnetic fields and breast cancer in women: a population-based study. Am J Epidemiol 2004; 159 (9): 852-861.

Labreche F, Goldberg MS, Valois MF, Nadon L, Richardson L, Lakhani R, Latreille B. Occupational exposures to extremely low frequency magnetic fields and postmenopausal breast cancer. Am J Ind Med 2003; 44 (6): 643 652 .

Laden F, Neas LM, Tolbert PE, et al. Electric blanket use and breast cancer in the nurses' health study, $A m J$ Epidemiol 2000; 152 (1): 41-49.

Lee GM, Neutra RR, Hristova L, Yost M, Hiatt RA. A nested case-control study of residential and personal magnetic field measures and miscarriages. Epidemiology 2002; 13 (1): 21-31.

Lee GM, Neutra RR, Hristova L, Yost M, Hiatt RA. The use of electric bed heaters and the risk of clinically recognized spontaneous abortion. Epidemiology 2000; 11 (4): 406-415.

Li DK, Neutra RR. Magnetic fields and miscarriage. Epidemiology 2002; 13 (2): 237-238.

Li DK, Odouli R, Wi S, et al. A population-based prospective cohort study of personal exposure to magnetic fields during pregnancy and the risk of miscarriage. Epidemiology 2002; 13 (1): 9-20.

Li CY, Sung FC. Association between occupational exposure to power frequency electromagnetic fields and amyotrophic lateral sclerosis: a review. Am J Ind Med 2003; 43 (2): 212-220.

London SJ, Pogoda JM, Hwang KL, et al. Residential magnetic field exposure and breast cancer risk: a nested case-control study from a multiethnic cohort in Los Angeles County, California. Am J Epidemiol 2003; 158 (10): 969-980.

McElroy JA, Newcomb PA, Trentham-Dietz A, Hampton JM, Kanarek MS, Remington PL. Endometrial cancer incidence in relation to electric blanket use. Am J Epidemiol 2002; 156 (3): 262-267.

McElroy JA, Newcomb PA, Remington PL, et al. Electric blanket or mattress cover use and breast cancer incidence in women 50-79 years of age. Epidemiology 2001; 12 (6): 613-617.

Minder CE, Pflüger DH. Leukemia, brain tumors, and exposure to extremely low frequency electromagnetic fields in Swiss railway employees. Am J Epidemiol 2001; 153 (9): 825-835.

Navas-Acien A, Pollan M, Gustavsson P, Floderus B, Plato N, Dosemeci M. Interactive effect of chemical substances and occupational electromagnetic field exposure on the risk of gliomas and meningiomas in Swedish men. Cancer Epidemiol Biomarkers Prev 2002; 11 (12): 1678-1683.

O'Leary ES, Schoenfeld ER, Henderson K, et al.; EBCLIS Group. Wire coding in the EMF and Breast Cancer on Long Island Study: relationship to magnetic fields. J Expo Anal Environ Epidemiol 2003; 13 (4): 283-293.

Pollan M, Gustavsson P, Floderus B. Breast cancer, occupation, and exposure to electromagnetic fields among Swedish men. Am J Ind Med 2001; 39 (3): 276-285.

Robert E. Intrauterine effects of electromagnetic fields - (low frequency, mid-frequency RF, and microwave): review of epidemiologic studies. Teratology 1999; 59 (4): 292-298.

Sahl J, Mezei G, Kavet R, McMillan A, Silvers A, Sastre A, Kheifets L. Occupational magnetic field exposure and cardiovascular mortality in a cohort of electric utility workers. Am J Epidemiol 2002; 156 (10): 913-918.

Savitz D. Magnetic fields and miscarriage. Epidemiology 2002; 13 (1): 1-4. 
Savitz DA, Cai J, van Wijngaarden E, et al. Case-cohort analysis of brain cancer and leukemia in electric utility workers using a refined magnetic field job-exposure matrix. Am J Ind Med 2000; 38 (4): 417-425.

Schüz J, Grigat JP, Brinkmann K, Michaelis J. Residential magnetic fields as a risk factor for childhood acute leukaemia: Results from a German population-based case-control study. Int J Cancer 2001; 91 (5): 728-735.

Schoenfeld ER, O'Leary ES, Henderson K, et al.; EBCLIS Group. Electromagnetic fields and breast cancer on Long Island: a case-control study. Am J Epidemiol 2003; 158 (1): 47-58.

Shaw GM. Adverse human outcomes and electromagnetic fields: A brief summary of the epidemiologic literature. Bioelectromagnetics 2001; Suppl 5: S5-S18.

Sorahan T, Nichols L. Mortality from cardiovascular disease in relation to magnetic field exposure: findings from a study of UK electricity generation and transmission workers, 1973-1997. Am J Ind Med 2004; 45 (1): $93-$ 102.

Sorahan T, Nichols L, van Tongeren M, Harrington JM. Occupational exposure to magnetic fields relative to mortality from brain tumours: updated and revised findings from a study of United Kingdom electricity generation and transmission workers, 1973-97. Occup Environ Med 2001; 58 (10): 626-630.

Skinner J, Mee TJ, Blackwell RP, et al.; United Kingdom Childhood Cancer Study Investigators. Exposure to power frequency electric fields and the risk of childhood cancer in the UK. Br J Cancer 2002; 87 (11): 1257 1266.

Söderberg KC, Naumburg E, Anger G, Cnattingius S, Ekbom A, Feychting M. Childhood leukemia and magnetic fields in infant incubators. Epidemiology 2002; 13 (1): 45-49.

Tynes T, Klæboe L, Haldorsen T. Residential and occupational exposure to residential and occupational exposure to $50 \mathrm{~Hz}$ magnetic fields and malignant melanoma: a population-based study. Occup Environ Med $2003 ; 60$ (5): 343-347.

Tynes T, Haldorsen T. Residential and occupational exposure to $50 \mathrm{~Hz}$ magnetic fields and hematological cancers in Norway. Cancer Causes Control 2003; 14 (8): 715-720.

UK Childhood Cancer Study Investigators. Childhood cancer and residential proximity to power lines. $B r J$ Cancer 2000; 83 (11): 1573-1580.

Van Wijngaarden E, Nylander-French LA, Millikan RC, Savitz DA, Loomis D. Population-based case-control study of occupational exposure to electromagnetic fields and breast cancer. Ann Epidemiol 2001; 11 (5): 297 303.

Van Wijngaarden E, Savitz DA, Kleckner RC, Cai J, Loomis D. Exposure to electromagnetic fields and suicide among electric utility workers: a nested case-control study. Occup Environ Med 2000; 57 (4): 258-263.

Villeneuve PJ, Agnew DA, Miller AB, Corey PN, Purdham JT. Leukemia in electric utility workers: The evaluation of alternative indices of exposure to $60 \mathrm{~Hz}$ electric and magnetic fields. Am J Ind Med 2000a; 37 (6): 607-617.

Villeneuve PJ, Agnew DA, Miller AB, Corey PN. Non-Hodgkin's lymphoma among electric utility workers in Ontario: the evaluation of alternate indices of exposure to $60 \mathrm{~Hz}$ electric and magnetic fields. Occup Environ Med 2000b; 57 (4): 249-257.

Villeneuve PJ, Agnew DA, Johnson KC, Mao Y. Brain cancer and occupational exposure to magnetic fields among men: results from a Canadian population-based case-control study. Int J Epidemiol 2002; 31 (1): 210 217.

Willett EV, McKinney PA, Fear NT, Cartwright RA, Roman E. Occupational exposure to electromagnetic fields and acute leukaemia: analysis of a case-control study. Occup Environ Med 2003; 60 (8): 577-583.

Zheng T, Cantor KP, Zhang Y, Keim S, Lynch CF. Occupational risk factors for brain cancer: a population-based case-control study in Iowa. J Occup Environ Med 2001; 43 (4): 317-324.

Zheng T, Holford TR, Mayne ST, et al. Exposure to electromagnetic fields from use of electric blankets and other in-home electrical appliances and breast cancer risk. Am J Epidemiol 2000; 151 (11): 1103-1111.

Zhu K, Hunter S, Payne-Wilks K, Roland CL, Forbes DS. Use of electric bedding devices and risk of breast cancer in African-American women. Am J Epidemiol 2003; 158 (8): 798-806. 